\title{
Model Development of Management Information System of Internship
}

\author{
Wahyu Hardyanto ${ }^{1}$, Aji Purwinarko ${ }^{2}$, I Made Sudana ${ }^{3}$, Eko Supraptono ${ }^{4}$ \\ ${ }^{1}$ Physics Department, Faculty of Mathematics and Natural Sciences, Universitas Negeri Semarang \\ ${ }^{2}$ Computer Sciences Department, Faculty of Mathematics and Natural Sciences, Universitas Negeri Semarang \\ ${ }^{3}$ Electrical Engineering Department, Faculty of Engineering, Universitas Negeri Semarang \\ ${ }^{4}$ Teaching Management Department, Faculty of Engineering, Universitas Negeri Semarang \\ Corresponding email: hardy@ mail.unnes.ac.id.
}

\begin{abstract}
The management of internship is generally done by working groups where management still uses management manually, data collection of students and companies or institutions of the industrial world has not been arranged systematically. : (1) bringing students to be placed in the industrialized world, (2) conducting monitoring visits of students in the industrial world at mid-time of the internship, (3) withdrawing students from the industrial world at the end of implementation time.At the end of the implementation of street vendors, every student will get an assessment from the industrial world which then published in the form of certificates. However, sometimes the issuance of this certificate is constrained because the processing is also still manual starting from the input process value up to print the document, so it takes time in the process of making it. So we need an information system that can be used to manage the information. Information systems are designed using the waterfall model. This research will produce an integrated of internship management information system between higher education institutions and industry.
\end{abstract}

Keywords: Internship, Waterfall Model

\section{Introduction}

Apprenticeship management is generally carried out by working groups that still use management manually. Data collection of students and companies or the world world has not been systematically arranged: (1) escorting students to be placed in the industrial world, (2) supervising students in the industrial world in the time season conducting internships, (3) doing the work of students from the industrial world at the end of the implementation period.

During the visit monitoring task, pending only carried out one monitoring, and the process of supervising student activities. The communication intensity of students and mentoring teachers is practically very lacking too. Realities that occur on the surface many companion teachers often do not know what people do in industrial places that are very fast, such as in the internship and activities carried out

Every student who is an apprentice has been provided with a daily journal book, but this is considered to be less effective. News of the absence of students due to illness and no new information when the accompanying teacher monitored the visit. This is happening because monitoring is not carried out every day. Process monitoring is constrained by various factors.

The presence of students in places becomes a point of discipline, but only as a formality. There are many cases in the field that do not appear regularly on a regular basis but are carried out on their own. Problems such as this can be minimized if the tutor does routine monitoring.

At the end of the internship, each student will get information from the industrial world which is then issued in the form of a certificate. However, sometimes this report is constrained due to processing and still manual starting from the input process to reaching the certificate, requiring time in the manufacturing process.

From the above problems, we need solutions to these problems. The amount of data or information that must be processed certainly cannot be done using the manual method. College as one of the educational institutions must have a good education. This is especially the management that regulates the activities of students carrying out internships. Thus we use a system based on technology and information as a result of the implementation of apprenticeship.

\section{Methods}

An article by Walter Royce (Patel et al.. 2013) published the first model waterfall. By modifying the old model that was heavily criticized, produced a different and new model. In principle, the waterfall model for flexible design before carrying out a wild code program in building a system. Waterfall model has the primary function to ensure a project. The Waterfall method has several stages in software 
development, which consists of needs analysis, design, implementation, testing, and maintenance (Vijayasarathy \& Butler, 2016)

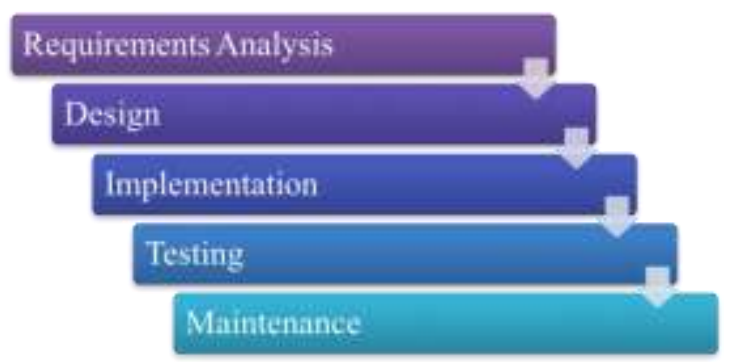

Figure 1. The stages of Waterfall Model (Hardyanto et al., 2017)

\subsection{Requirements Analysis}

This stage is called Software Required Specification (SRS). The main goal is to describe the software that will be built thoroughly. In this stage, it takes some work that needs to be done to find out functional and nonfunctional needs. Must be filled with data on the purpose, function, user, interface, scope, perspective, and database. The need for nonfunctional loads on the basis, limits, limitations, and performance of software (Bassil, 2012).

2.2 Design

The design stage is not only about interface design but is related to algorithm design, database, concept design, structural design, and software architecture design. Software design and system are built based on the requirements specification in the first stage. The design of a system will help determine hardware requirements and define the entire architecture system.

\subsection{Implementation}

The implementation stage is the realization of all business needs and system design into an application. At this stage, all code is written and compiled into an operational application. This stage is divided into modular forms to facilitate application development in teamwork. This stage is software development so that it is the longest stage in SDLC (Purwinarko \& Sukestiyarno, 2014).

\subsection{Testing}

This stage is known as verification and validation. The process is to check that software meets the requirements and objectives that have been set. Verification is a software evaluation process in determining whether a product from the given development phase meets the conditions imposed at the beginning of that stage. While validation is the process of evaluating software during or at the end of the development process to determine whether it meets the specified requirements or not (Mone, 2015; Alshamrani \& Bahattab, 2015).

\subsection{Maintenance}

This process is done to modify the software after it is created and used, fix errors, and improve performance and quality. This phase includes additional maintenance activities including software adaptation to the environment, as an activity to accommodate the needs of new users, and improve software capabilities

\section{Results and Discussion}

This research produces an information system that can be accessed through the http://karir.lp3.unnes.ac.id page. The appearance of the system is shown in Figure 2. Where this research will be used by active students and alumni.

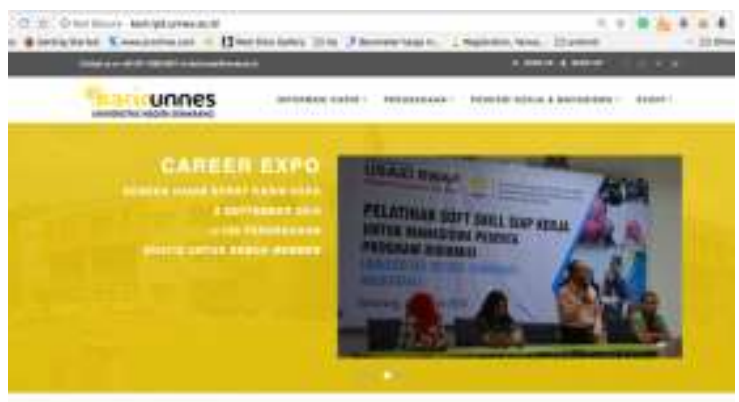

Figure 2. Main page.

This main page consists of four menus, namely company career information, education, internships, and tests. The career information menu is shown in Figure 3.

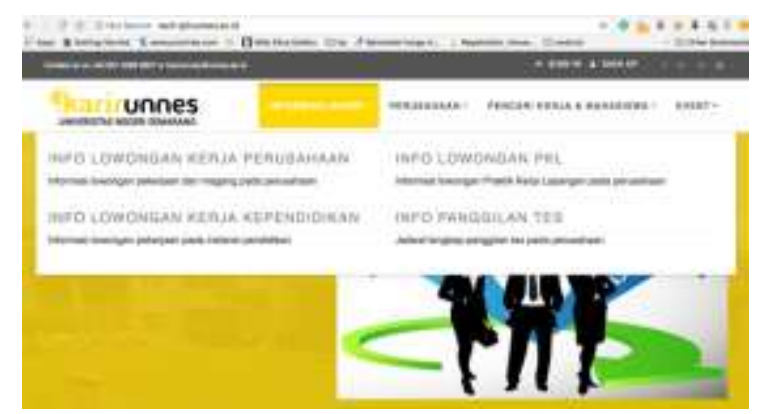

Figure 3. Career information menu.

Internship information can be accessed by students through the "Info Lowongan PKL" submenu. The appearance of this submenu is shown in Figure 4. 


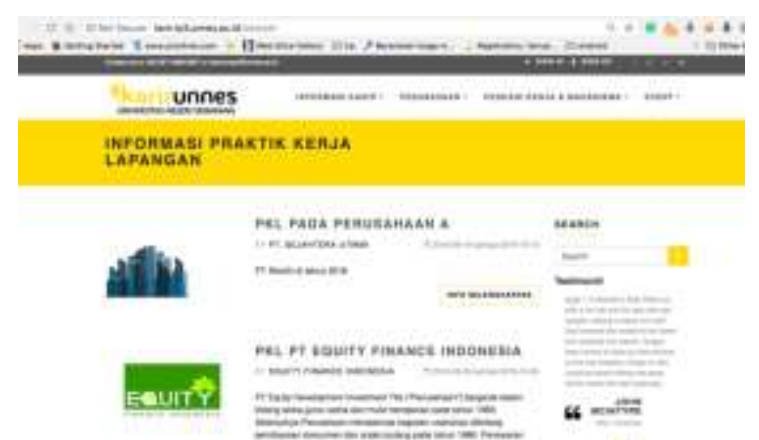

Figure 4. Internship information

Companies can enter apprenticeship information through the account they already have. The admin menu can be accessed via the http://karir.lp3.unnes.ac.id/backend page so that the login page will appear in the system as shown in Figure 5.

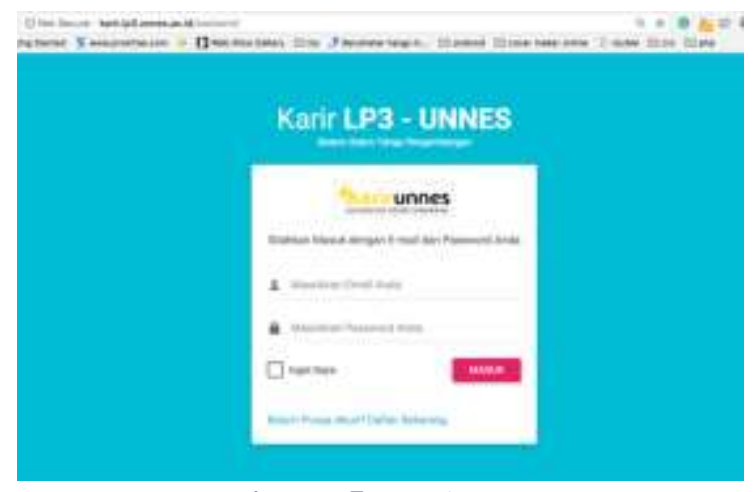

Figure 5. Login page

After successfully logging in, the company web page will be entered, as shown in Figure 6 .

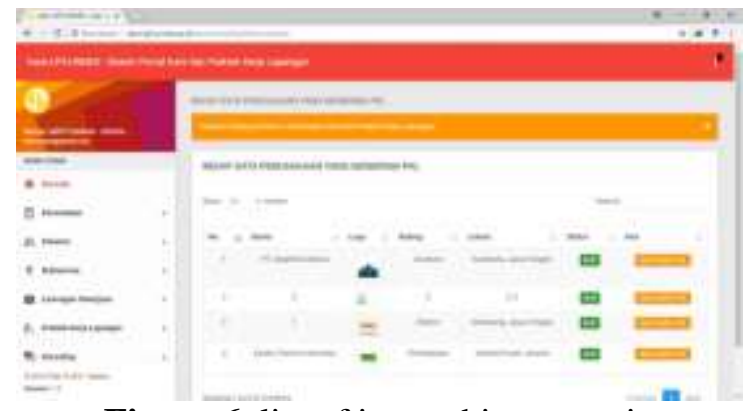

Figure 6. list of internship vacancies.

Figure 6 is the list of internship vacancies in the company. Companies can enter apprenticeship information through the input form as shown in Figure 7.

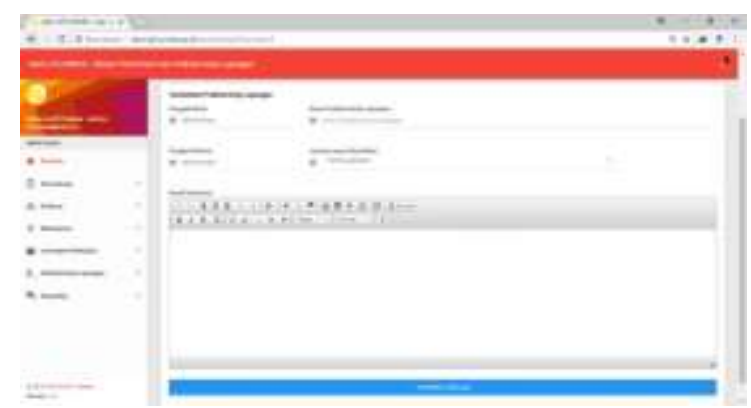

Figure 7. Internship input form

\section{Conclusion}

Based on the results achieved, the waterfall model is still relevant to be used to develop internal-based applications. This model is simple, easy to understand and implement in making applications [8-10]. This model works well and produces results that are in line with expectations; this is shown based on the results of application development that has been carried out. The application that has produced this can be the answer to the problem of managing information that occurs in the apprenticeship process. The apprenticeship information posted by the company can be accessed directly by students, so students who meet the criteria can be directly applied to the information system. Also, this system also provides the advantage that a student's internship history will be recorded well and the results can be monitored directly by the teacher or company.

\section{References}

Patel, U. A., \& Jain, N. K. (2013). New idea in waterfall model for real-time software development. International Journal of Engineering Research \& Technology (IJERT), 2(4), 115.

Vijayasarathy, L. R., \& Butler, C. W. (2016). Choice of software development methodologies: Do organizational, project, and team characteristics matter?. IEEE Software, 33(5), 86-94.

Hardyanto, W., Purwinarko, A., Sujito, F., \& Alighiri, D. (2017). Applying an MVC Framework for The System Development Life Cycle with Waterfall Model Extended. InJournal of Physics: Conference Series (Vol. 824, No. 1, p. 012007). IOP Publishing. 
Bassil, Y., (2012). A Simulation Model for the Waterfall Software Development Life Cycle. International Journal of Engineering and Technology, May, 2(5), pp. 742-749.

Purwinarko A and Y. L. Sukestiyarno, (2014). Model Expertise Management System di Universitas Negeri Semarang. Sci. J. Informatics, vol. 1, no. 2, pp. 177-184.

Mone SD. (2015). Comparative study of Waterfall model with RAD model. International Journal of Modern Trends in Engineering, pp. 481-484,

Alshamrani, A., \& Bahattab, A. (2015). A comparison of three SDLC models waterfall model, spiral model, and
Incrementa1/Iterative model. International Journal of Computer Science Issues (IJCSI), 12(1), 106.

Chandra, V. (2015). Comparison between various software development methodologies. International Journal of Computer Applications, 131(9), 7-10.

Shylesh, S. (2017). A Study of Software Development Life Cycle Process Models. In National Conference on Reinventing Opportunities in Management, IT, and Social Sciences (pp. 534-541).

Kramer, M. (2018). Best Practices In Systems Development Lifecycle: An Analyses Based On The Waterfall Model. Review of Business and Finance Studies, 9(1), 77-84. 